\title{
Clearance-inducing antibodies are responsible for protection against the acute phase of Trypanosoma cruzi infection in mice
}

\author{
L.F. Umekita, \\ D.P. Ramos and I. Mota
}

Laboratório de Imunopatologia, Instituto Butantan, São Paulo, SP, Brasil

\section{Correspondence L.F. Umekita \\ Laboratório de Imunopatologia \\ Instituto Butantan \\ Av. Vital Brasil, 1500 \\ 05503-900 São Paulo, SP \\ Brasil \\ Fax: 55 (011) 815-1505}

Publication supported by FAPESP.

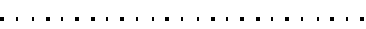

Received December 17, 1996 Accepted July 28, 1997

\begin{abstract}
A study was conducted on mice infected with strains $\mathrm{Y}$ and $\mathrm{CL}$ of Trypanosoma cruzi. The ability of anti-Y and anti-CL sera to induce complement-mediated lysis, immune clearance and protection against the acute phase of the infection was studied using homologous anti-Y or anti-CL serum tested with the $\mathrm{Y}$ or CL strain, or heterologous anti$\mathrm{Y}$ serum tested with the CL strain or anti-CL serum tested with the $\mathrm{Y}$ strain. Complement-mediated lysis was induced by both homologous and heterologous antisera but protection was afforded only by homologous antisera. Immune clearance was induced by homologous but not by heterologous antisera. Antisera with high clearance ability were able to confer protection whereas antisera with high lytic ability were not. These results show a high correlation between the antibody ability to induce clearance and to confer protection and suggest that clearance rather than lysis is responsible for protection against the acute phase of the infection. The mechanism of antibody protection against the acute phase of the infection is discussed.
\end{abstract}

Key words

- Trypanosoma cruzi

- Clearance

- Complement-mediated lysis

- Protection

\section{Introduction}

The presence of a strong humoral immune response to Trypanosoma cruzi has been consistently demonstrated in patients with Chagas' disease as well as in laboratory animals experimentally infected with parasites. Krettli and Brener (1) and McHardy (2) were the first to protect mice against the acute phase of $T$. cruzi infection by passive transfer of immune serum. The protective activity is due to antibodies of the IgG isotype (3-5). However, the intrinsic mechanism of protection afforded by anti- $T$. cruzi antibodies is still unknown. Two conspicuous biological activities of these antibodies are their ability to induce complement-mediated lysis (CML) of bloodstream trypomastigotes (Btrys) in vitro and clearance of these parasite forms when actively or passively injected into immunized mice (6-9). However, which of these antibody abilities is responsible for protection has not yet been established. We report here the results of experiments suggesting that protection against the acute phase of $T$. cruzi infection is due to the 
ability of antibodies to induce clearance and not to their ability to induce lysis.

\section{Material and Methods}

Animals

A/Sn mice weighing 16-18 $\mathrm{g}$ reared at the animal house of the Laboratory of Immunopathology, Instituto Butantan, were used.

\section{T. cruzi strains}

The Y strain was kindly provided by Dr. Zigman Brener, Department of Parasitology, University of Minas Gerais, Brazil, and has been maintained in our laboratory by infection of mice. Microscopic examination of the bloodstream parasites showed a predominance of slender forms and infected animals showed a parasitemic peak by about the 7 th postinfection day.

The CL strain was kindly supplied by Dr. Eufrosina S. Umezawa, Laboratory of Protozoology, Institute of Tropical Medicine, São Paulo, Brazil, and has been maintained in our laboratory by infection of mice. Microscopic examination of the bloodstream parasites showed a predominance of stout forms and infected animals showed a parasitemic peak by about the 14 th postinfection day.

\section{Maintenance of $T$. cruzi}

Blood samples from infected mice were obtained on days 7 (Y strain) and 14 (CL strain) of infection by puncture of the ophthalmic plexus and immediately suspended in a $3.8 \%$ sodium citrate solution. The number of bloodstream trypomastigotes (Btrys) in these suspensions was determined with a Neubauer chamber and adjusted with 0.15 $\mathrm{M} \mathrm{NaCl}$ to approximately $5 \times 10^{5} / \mathrm{ml}$ (Y strain) and $2.5 \times 10^{4} / \mathrm{ml}$ (CL strain). To maintain the infection, the parasites were transferred to normal mice by intraperito- neal (ip) injection of $0.2 \mathrm{ml}$ of the parasite suspensions.

\section{Infection}

Mice were infected $i p$ with $10 \mathrm{Y}$ or CL Btrys freshly isolated from the blood of the animals used to maintain the parasites. The course of parasitemia in the infected animals was determined after 7 days of infection by daily counts of the parasites in fresh blood samples obtained from the ophthalmic plexus. Under these conditions, the infected animals presented a parasitemia peak by about the 10 th $(\mathrm{Y})$ or 15 th $(\mathrm{CL})$ day and died between 16 to $20(\mathrm{Y})$ and 24 to 26 (CL) days after infection.

\section{Antibody-free parasites}

Mice were infected by the $i p$ route with $2.5 \times 10^{4}$ Btrys of the $\mathrm{Y}$ strain or $5 \times 10^{3}$ Btrys of the CL strain and injected ip with cyclophosphamide (200 mg/kg) after $48 \mathrm{~h}$ to suppress antibody production. Seven (Y) or 14 (CL) days after infection the animals were bled by cardiac puncture and the antibodyfree parasites were obtained as previously described (9).

\section{Chronic antiserum to $\mathrm{Y}$ or $\mathrm{CL}$ strains}

Mice were infected $i p$ with 10 Btrys of the $\mathrm{Y}$ or CL strain. To prevent death by acute infection $1 \mathrm{~g} / \mathrm{kg}$ benzimidazole (N-benzyl-2nitro-1-imidazoacetamide) dissolved in water was administered by gavage 9 to 10 days after infection when parasites were present in blood. The animals were kept for 45 days, after which they were challenged $i p$ with 100 Btrys of the $\mathrm{Y}$ or CL strain. Ten days later the animals of both groups were bled, serum was collected separately and either used immediately or stored at $-20^{\circ} \mathrm{C}$. In this way we obtained chronic antiserum to the $\mathrm{Y}$ or $\mathrm{CL}$ strain. Both antisera had high lytic and clearance abilities, were able to confer protection 
and contained IgG antibodies directed against epitopes present on the membrane of living trypomastigotes.

\section{Complement-mediated lysis}

CML assays were carried out as previously described by Krettli (8) with slight modifications. Twenty-five microliters of an antibody-free Btry suspension (4 x 106/ml) was added to $100 \mu \mathrm{l}$ of immune serum and the mixture was incubated for $30 \mathrm{~min}$ at $37^{\circ} \mathrm{C}$. After incubation an equal volume of normal or heat-inactivated human serum was added and the mixture was incubated for an additional $40 \mathrm{~min}$ at $37^{\circ} \mathrm{C}$. The samples were then immediately transferred to an ice bath, the number of motile Btrys was determined with a Neubauer chamber and the percentage of lysis was calculated.

\section{Clearance test}

Antibody-free Btrys of the CL or Y strains $\left(0.2 \mathrm{ml}\right.$ of a $1 \times 10^{7}$ Btry suspension) were injected intravenously (iv) into normal or passively immunized mice and the rate of parasite removal from peripheral blood (clearance) was measured as previously reported (9).

\section{Passive immunization}

Mice were passively immunized with an $i v$ injection of $0.2 \mathrm{ml}$ anti-Y or anti-CL serum. This volume of each antiserum was sufficient to induce $100 \%$ clearance within $15 \mathrm{~min}$. Control animals were injected with $0.2 \mathrm{ml}$ normal mouse serum.

\section{Protective ability}

To determine the ability of antisera to protect against death during the acute phase of infection, mice were injected $i v$ with 0.4 $\mathrm{ml}$ (this volume was required to induce $100 \%$ protection against death) of anti-Y or anti-
CL serum and 30 min later were infected ip with $10 \mathrm{Y}$ or CL Btrys. Parasitemia and animal survival were used as criteria of protection.

\section{CML and clearance abilities of homologous and heterologous antisera}

The ability of anti-Y and anti-CL sera to induce complement-mediated lysis, clearance or protection against the acute phase of the infection was studied using the homologous system (anti-Y or anti-CL serum tested with the $\mathrm{Y}$ or CL strain, respectively) or the heterologous system (anti-Y serum vs CL strain or anti-CL serum $v s \mathrm{Y}$ strain).

\section{Results}

CML and clearance induced by homologous or heterologous antiserum

The ability of anti-Y and anti-CL sera to induce CML and clearance of $\mathrm{Y}$ and $\mathrm{CL}$ Btrys is shown in Table 1. As can be seen, a high percentage of lysis was induced by both homologous and heterologous antisera whereas a high percentage of clearance was induced only when homologous antisera were used.

\section{Protection induced by homologous or} heterologous antiserum

As shown in Table 1, mice that received

Table 1 - Ability of antisera to Y or CL bloodstream trypomastigotes (Btrys) to induce homologous or heterologous complement-mediated lysis (CML), clearance and protection.

\begin{tabular}{lcccc}
\hline Serum & Btrys & $\begin{array}{c}\text { CML } \\
(\%)\end{array}$ & $\begin{array}{c}\text { Clearance } \\
(\%)\end{array}$ & $\begin{array}{c}\text { Protection } \\
(\%)\end{array}$ \\
\hline anti-Y & $Y$ & 100 & 100 & 100 \\
& $\mathrm{CL}$ & 77.6 & 5.2 & 0 \\
anti-CL & $\mathrm{Y}$ & 76.0 & 12.5 & 0 \\
& $\mathrm{CL}$ & 100 & 100 & 100
\end{tabular}


anti-Y or anti-CL serum prior to infection with either $\mathrm{Y}$ or CL Btrys were protected against the infection only when antiserum with a high clearance ability was used. Figure 1 shows the parasitemia and mortality of mice pretreated with anti-Y or anti-CL serum before infection with Y Btrys, and Figure 2 shows the parasitemia and mortality of mice pretreated with anti-Y or anti-CL serum before infection with CL Btrys. As can be seen, a significant reduction in parasitemia
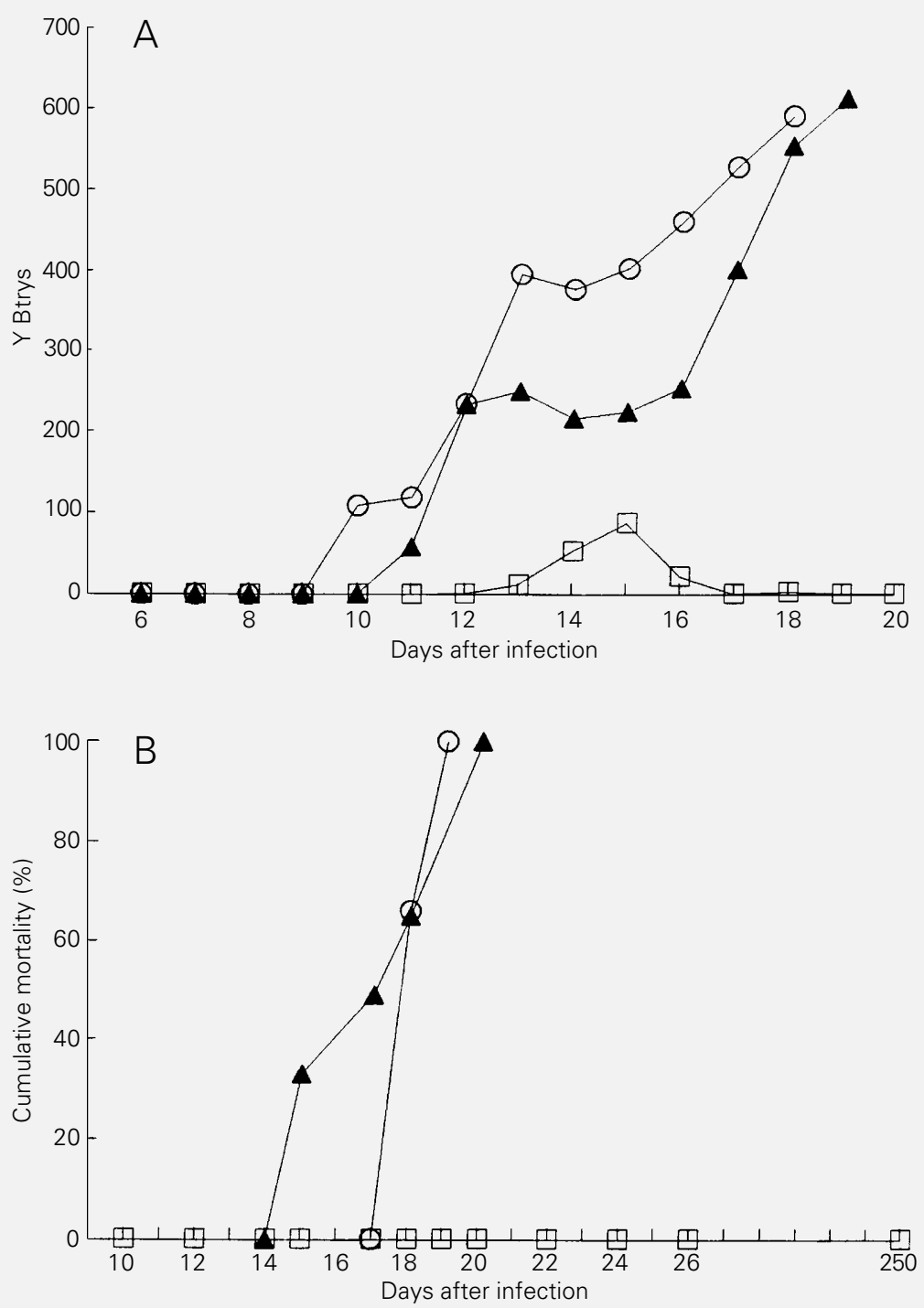

Figure 1 - Parasitemia (A) and mortality (B) of mice pretreated iv with anti-Y (open squares) or anti-CL (filled triangles) serum before infection with bloodstream trypomastigotes (Btrys) of the $Y$ strain of Trypanosoma cruzi. Control animals were injected iv with normal mouse serum (open circles). Each point represents the mean of 6 animals. and mortality was only achieved with antisera with a high clearance ability whereas sera with high lytic ability did not change parasitemia or mortality.

\section{Discussion}

The importance of antibodies in resistance against the acute phase of $T$. cruzi infection has long been recognized (8). These antibodies can be detected either by conventional diagnostic tests such as immunofluorescence, ELISA and complement fixation which are performed using a soluble parasite extract or dead parasites, or by CML and immune clearance which can only be performed with living parasites (10-12). Antibodies with lytic and clearance ability share two peculiar characteristics: both are only efficiently induced after immunization with living parasites and both react with living but not with dead parasites (10-13). Krettli and Brener (10) have associated protection with the presence of lytic antibodies since only mice presenting these antibodies are resistant to infection and since these antibodies disappear in mice parasitologically cured after specific treatment. However, the presence of clearance-inducing antibodies was not investigated by the authors.

Protective antisera usually present both lytic and clearance activities, which appear simultaneously in the course of infection and achieve their maximum in the chronic phase of the disease (14). In fact, we have been unable to dissociate these activities in sera of chronically infected mice (Umekita LF, Ramos DP and Mota I, unpublished data). Thus, the passive transfer of protection by immune serum obtained from infected animals may be attributed to its lytic or clearance activity or to both. However, as reported here, when antisera obtained from animals infected with one strain were tested for their lytic and clearance ability with the other strain, it was possible to dissociate the two activities. For instance, when anti-Y 
sera (which have lytic and clearance ability when tested with the $\mathrm{Y}$ strain) were tested with the CL strain they presented lytic but no clearance ability. The same was the case when anti-CL sera against the Y strain were used. Additionally, when tested for their protective effect by passive transfer, anti-Y sera containing a high percentage of lytic activity against the CL strain did not protect against a fatal challenge with this strain. The same was the case when anti-CL sera containing a high percentage of lytic activity against the Y strain were used to protect against a challenge with the $\mathrm{Y}$ strain.

The present results show a high correlation between the antibody ability to induce clearance and protection and, conversely, a poor correlation between the antibody ability to induce lysis and protection. Thus, mice that received antiserum prior to infection became resistant only when antisera with a high content of clearance antibodies were used. As shown in Figures 1 and 2, all animals pretreated with antisera containing a high content of antibodies with clearance ability presented a lower parasitemia and mortality whereas animals pretreated with antisera containing antibodies with a high lytic ability soon reached parasitemia and mortality levels similar to those observed for control animals. Although homologous antisera with protective ability have both lytic and clearance abilities the observation that heterologous antisera with a high lytic ability showed no protection suggests that lysis may not be important for protection. In fact, although protective antisera have high in vitro lytic activity it has not been demonstrated that lysis of the parasites in vivo is responsible for protection. Conversely, there are many reports suggesting that protection is not mediated by lytic antibodies. Thus, it was observed that $\mathrm{C} 5$-deficient mice and C4-deficient guinea pigs infected with $T$. cruzi presented a course of infection similar to that of normocomplementemic animals showing that deficiency of $\mathrm{C} 5$, which is essential for complement-mediated lysis, had no effect on protection against $T$. cruzi infection $(8,15)$. Other authors working with rabbit and mouse anti-T. cruzi sera observed that not all lytic antibodies have a protective effect (16). Monoclonal antibodies against the metacyclic forms of the parasites have been obtained in several laboratories $(17,18)$ and it has been reported that some mono-
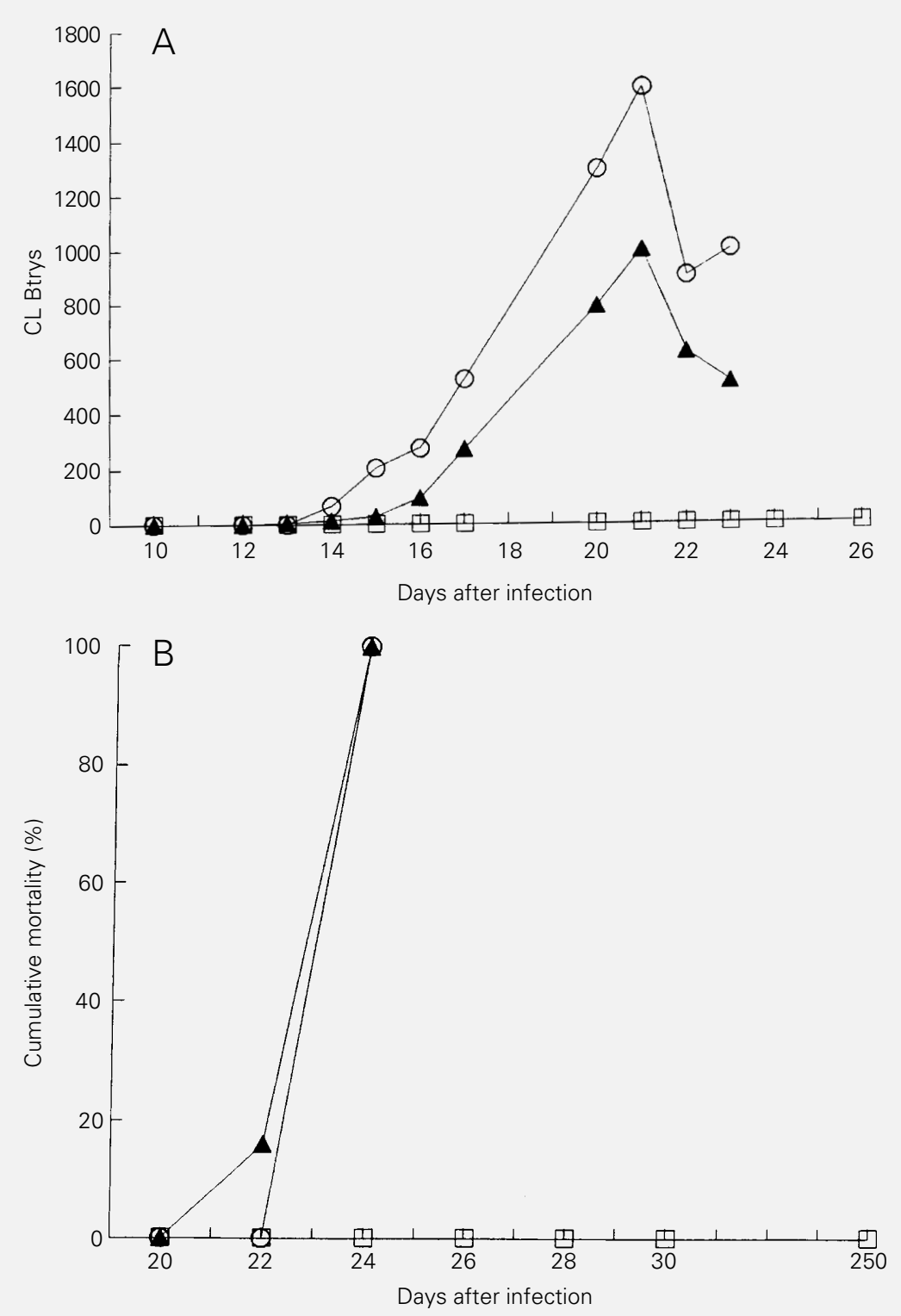

Figure 2 - Parasitemia (A) and mortality (B) of mice pretreated iv with anti-CL (open squares) or anti-Y (filled triangles) serum before infection with bloodstream trypomastigotes (Btrys) of the CL strain of Trypanosoma cruzi. Control animals were injected iv with normal mouse serum (open circles). Each point represents the mean of 6 animals. 
clonal antibodies in spite of having protective ability are unable to lyse the parasites (19). Furthermore, Umekita et al. (9) reported that the $\mathrm{Fc}$ domain of the antibody molecule is required for parasite clearance and that $\mathrm{F}(\mathrm{ab}$ ') 2 fragments, although able to induce lysis, are unable to induce clearance. Other experiments have suggested an association between the presence of $\mathrm{C} 3$, protection and clearance antibodies. For instance, $\mathrm{C} 3$ depletion induced by cobra venom factor resulted in increased parasitemia and mortality of $T$. cruzi-infected mice (7) and completely abolished the clearance of Btrys induced by anti- $T$. cruzi antibodies (20).

It was noted in the protection experiments that the reduction in parasitemia presented by animals infected with CL Btrys and receiving anti-CL serum was higher than that of animals infected with Y Btrys and receiving anti- $Y$ serum (see Figures 1 and 2). This seems to agree with previous observations showing that the antibody content as assayed by ELISA and clearance ability is usually higher in anti-CL serum than in antiY serum (12). However, no difference in mortality rate was observed between groups. Our experiments showing that animals passively immunized with anti-CL serum were protected against death in the acute phase induced by CL trypomastigotes are at first sight opposite to those of Krettli and Brener (1) who studied the effect of in vitro preincubation of $Y$ and CL trypomastigotes with immune serum on the agglutination and infectivity of the parasites. These authors reported that $Y$ trypomastigotes were agglutinated by anti-CL or anti-Y immune serum and had their infectivity decreased whereas CL trypomastigotes remained unchanged with neither agglutination nor decline of infectivity being observed after incubation with anti-Y or anti-CL immune serum. However, it should be pointed out that, while we protected the animals in vivo by passive immunization, Krettli and Brener (1) tried protection by pre-incubating the parasites in vitro before infection.

Brener (6), studying parasitemia of the Berenice strain (91\% slender forms) and the FL strain (92\% stout forms) in normal and infected animals, reported that the parasitemia of the stout forms was much more persistent than that of the slender forms both in normal and infected animals. In this situation, he detected parasitemia in chronically infected animals injected with the FL strain up to 3 days. In our experiments we determined the parasitemia in animals passively immunized with anti-CL serum and then infected with CL trypomastigote forms. Under these conditions, we found no detectable parasitemia. The apparent discrepancy between the parasitemia reported by Brener (6) and by us is probably due to the much larger number of trypomastigotes used in Brener's experiments $(1,200,000$ parasites per animal) compared with the small number of trypomastigotes used in our experiments (10 parasites per animal).

Taken together, our previous (12) and present results suggest that clearance-inducing antibodies are directed to epitopes specific for each strain. This implies that clearance and lytic antibodies should differ in their specificity. However, these data do not rule out the possibility that clearance antibodies are also able to cause lysis. Nevertheless, all the experimental data reported here strongly suggest that lysis is not important either for the removal of the parasites from circulation or for protection against the acute phase of the infection. In fact, most of the data favor the hypothesis that protection afforded by antibodies is due to their ability to opsonize trypomastigotes, thus enhancing phagocytosis by the mononuclear phagocytic system, as we have previously suggested (9). In this respect, it is pertinent to cite the recent paper by Franquini et al. (21) who, using non-lytic anti-T. cruzi monoclonal antibody, correlated parasite opsonization and phagocytosis with protective immunity against $T$. cruzi. 


\section{References}

1. Krettli AU \& Brener Z (1976). Protective effects of specific antibodies in Trypanosoma cruzi infection. Journal of Immunology, 116: 755-760.

2. McHardy N (1977). Passive immunization of mice against Trypanosoma cruzi using convalescent mouse serum. Zeitschrift für Tropenmedizin und Parasitologie, 28: 195-201.

3. Castelo Branco AZCL (1978). Proteção mediada por imunoglobulina $G$ em camundongos infectados com Trypanosoma cruzi. Master's thesis, UFMG, Belo Horizonte, MG, Brazil.

4. Takehara HA \& Mota I (1979). Role of different antibody classes in protection against Trypanosoma cruzi infection in mice. Abstracts of the International Congress on Chagas' Disease, Rio de Janeiro, RJ, Brazil, 157.

5. Takehara HA, Perini A \& Mota I (1981). Trypanosoma cruzi: role of different antibody classes in protection against infection in the mouse. Experimental Parasitology, 52: 137-146.

6. Brener Z (1969). The behavior of slender and stout forms of Trypanosoma cruzi in the bloodstream of normal and immune mice. Annals of Tropical Medicine and Parasitology, 63: 215-220.

7. Budzko DB, Pizzimenti MC \& Kierszenbaum F (1975). Effects of complement depletion in experimental Chagas' disease: immune lysis of virulent bloodforms of Trypanosoma cruzi. Infection and Immunity, 11: 86-91.

8. Krettli AU (1978). Efeito de anticorpos e do complemento sobre tripomastigotas sanguíneos de camundongos infectados com Trypanosoma cruzi. Doctoral thesis, Instituto de Ciências Biológicas, UFMG, Belo Horizonte, MG, Brazil.
9. Umekita LF, Takehara HA \& Mota I (1988). Role of the antibody Fc in the immune clearance of Trypanosoma cruzi. Immunology Letters, 17: 85-89.

10. Krettli AU \& Brener Z (1982). Resistance against Trypanosoma cruzi associated to anti-living trypomastigote antibodies. Journal of Immunology, 128: 2009-2012.

11. Umekita LF, Takehara HA \& Mota I (1993). Antibody specificity and clearance of $Y$ and CL strains of T. cruzi. Memórias do Instituto Oswaldo Cruz, 88: 199 (Abstract).

12. Umekita LF, Barbaro KC \& Mota I (1996). Specificity and role of anti-Trypanosoma cruzi clearance antibodies. Brazilian Journal of Medical and Biological Research, 29: 25-31.

13. Mota I \& Umekita LF (1994). Efeito da absorção do soro anti-T. cruzi (cepa $Y$ ) com tripomastigotas $Y$ vivos ou fixados sobre o clearance passivo. Annals of the 46th Annual Meeting of the Brazilian Society for Advancement of Science, Florianópolis, SC, Brazil, 781.

14. Krettli AU (1984). Protective antibodies in Trypanosoma cruzi infection: detection, functional activity and possible mechanisms of trypomastigotes killing in vivo and in vitro. Memórias do Instituto Oswaldo Cruz, 79 (Suppl): 59-66.

15. Dalmasso AP \& Jarvinen JA (1980). Experimental Chagas' disease in complement-deficient mice and guinea pigs. Infection and Immunity, 28: 434-440.

16. Umezawa ES, Stolf AMS, Colli W \& Zingales B (1987). Trypanosoma cruzi antigens recognized by lytic antibodies. Memórias do Instituto Oswaldo Cruz, 82: 135 (Abstract).
17. Chao D \& Dusanic DG (1985). Monoclonal antibodies to metacyclic stage antigens of Trypanosoma cruzi. American Journal of Tropical Medicine and Hygiene, 34: 694-701.

18. Yoshida N (1988). Imunidade contra formas metacíclicas do Trypanosoma cruzi: Identificação de antígenos de superfície e resistência a infecção aguda. "Livre-docência" thesis, Department of Microbiology, Immunology and Parasitology, Escola Paulista de Medicina, São Paulo, SP, Brazil.

19. Segura EL, Bua J, Camoanini AR, Subias E, Esteva M, Moreno M \& Ruiz AM (1986). Monoclonal antibodies against the flagellar fraction of epimastigotes of Trypanosoma cruzi. complement-mediated lytic activity against trypomastigotes and passive immunoprotection in mice. Immunology Letters, 13: 165-171.

20. Mota I \& Umekita LF (1989). The effect of C3 depletion on the clearance of Trypanosoma cruzi induced by IgG antibodies. Immunology Letters, 21: 223-226.

21. Franquini JR, Pereira-Chiocola VL, Schenkman S \& Rodrigues M (1996). Monoclonal antibody 3C9 eliminates $T$. cruzi trypomastigotes in vivo without mediating lysis in the presence of complement (CoML) or cells (ADCC). Memórias do Instituto Oswaldo Cruz, 91: 253 (Abstract). 